RECONNAISSANCE OF TOXIC SUBSTANCES IN THE

JORDAN RIVER, SALT LAKE COUNTY, UTAH

by Kendal I R. Thompson

U. S. GEOLOGICAL SURVEY

Water-Resources Investigations Report 84-4155

Prepared in cooperation with the

SALT LAKE COUNTY DIV ISION OF FLOOD

CONTROL AND WATER QUAL ITY

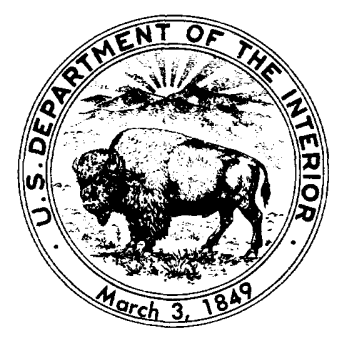

Sal + Lake City, Utah 1984 
UNITED STATES DEPARTMENT OF THE INTERIOR

WILLIAM P. CLARK, Secretary

GEOLOGICAL SURVEY

Dallas L. Peck, Director

\begin{tabular}{|c|c|}
\hline $\begin{array}{l}\text { For additional information } \\
\text { write to: }\end{array}$ & $\begin{array}{l}\text { Copies of the report can } \\
\text { be purchased from: }\end{array}$ \\
\hline $\begin{array}{l}\text { District Chief } \\
\text { U.S. Geological Survey } \\
1016 \text { Administration Building } \\
1745 \text { West } 1700 \text { South } \\
\text { Salt Lake City, Utah } 84014\end{array}$ & $\begin{array}{l}\text { Open-File Services Section } \\
\text { Western Distribution Branch } \\
\text { U.S. Geological Survey } \\
\text { Box 25425, Federal Center } \\
\text { Lakewood, Col orado } 80225 \\
\text { Telephone [(303) 234-5888] }\end{array}$ \\
\hline
\end{tabular}


Abstract ........................................... 1

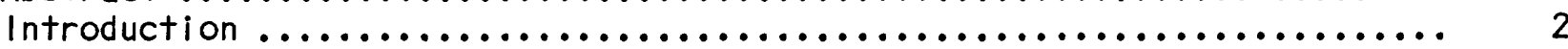

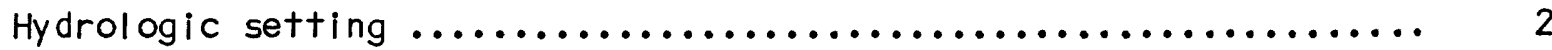

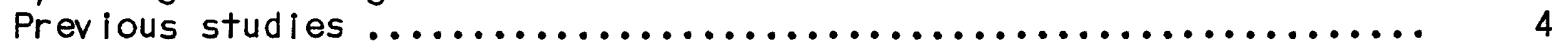

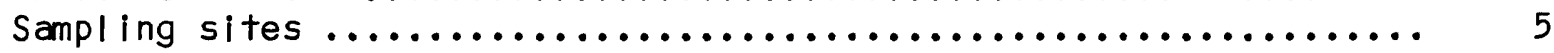

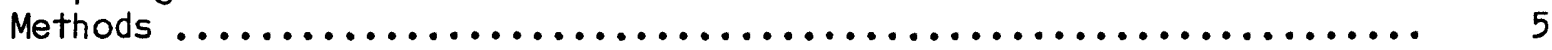

State stream-use $\mathrm{cl}$ asses and associated standards for

toxic substances ................................... 6

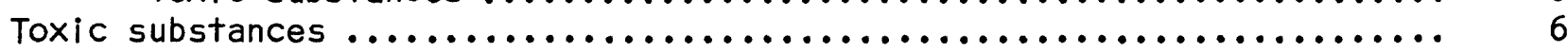

General discussion of toxic substances that exceeded

State standards in the Jordan River study area ............... 6

Distribution of toxic substances in the Jordan River

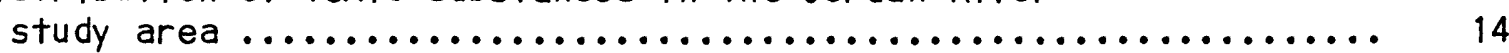

Toxic substances that exceeded state standards ............... 14

Organic toxic substances .............................. 16

Trace el ements in stream-bottom materials .................. 18

Toxic substances in storm runoff from urban areas ............... 20

Priority pollutants and additional trace elements in

storm runoff from urban areas detected in storm conduits .... 22

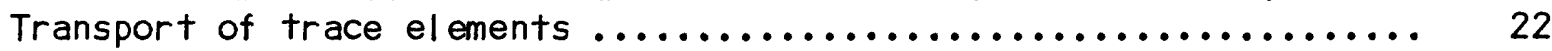

Transportation as a dissolved or suspended constituent ........ 26

Trace-el ement loads in the Jordan River ................... 26

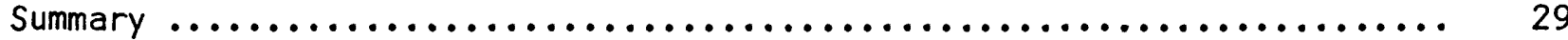

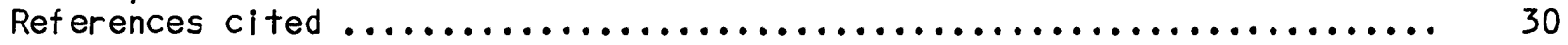

\section{ILLUSTRATION}

Figure 1. Map showing monitoring sites on and major inflow sources to the Jordan River in Salt Lake City, Utah ........

TABLES

Table 1. Classification of surface streams in Utah showing

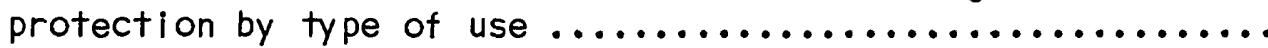

2. Classification of the Jordan River and three major tributaries in salt Lake County ......................

3. Numerical standards for protection of beneficial uses

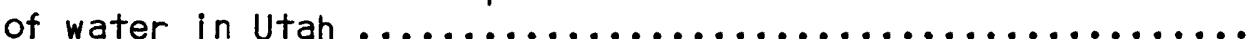

4. Numerical standards pertaining to toxic substances for protection of $\mathrm{Class} 3 \mathrm{C}$ water use in the Jordan River from Farmington Bay to North Temple Street in Salt Lake City 
Table 5. Selected toxic substances in the Jordan River and three

Page tributaries related to use classes and State standards.

6. Toxic substances that exceeded State standards in the Jordan

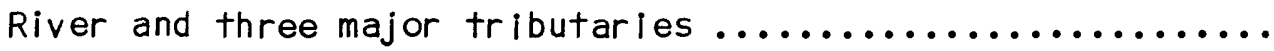

7. Concentrations of pesticides and PCB's detected in the

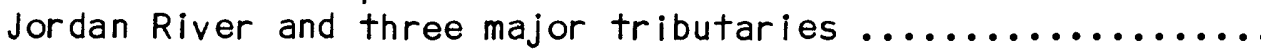

8. Concentrations of selected trace elements in bottom materials in the Jordan River and three major tributaries ............

9. Toxic substances that exceeded selected concentrations in storm conduits

10. Organic priority pollutants sampled on October 29, 1981, at six storm conduits

11. Selected metals, cyanide, and phenol in samples collected from six storm conduits on October 29, 1981, for analysis of priority pollutants

12. Trace-element concentrations in storm runoff on uctober 29,

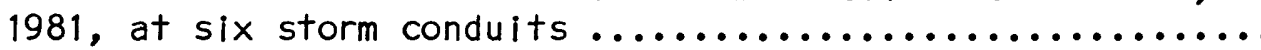

13. Part of selected trace elements transported in the dissolved phase in the Jordan River, Big Cottonwood, Little Cottonwood, and Mill Creeks .....................

14. Mean loads of selected trace el ements in the Jordan River for nonstorm periods .................... 
For readers who prefer to use metric units, conversion factors for inchpound units used in this report are listed below:

$\begin{array}{lcl}\text { Multiply inch-pound units } & \text { By } & \text { Io obtain metric units } \\ \text { foot } & 0.3048 & \text { meter } \\ \text { foot per mile } & 0.1894 & \text { meter per kilometer } \\ \text { inch } & 25.40 & \text { millimeter } \\ \text { mile } & 1.609 & \text { kilometer } \\ \text { pound per day } & 0.4536 & \text { kilogram per day }\end{array}$

Chemical concentration and water temperature are given only in metric units. Chemical concentration is given in milligrams per liter (mg/L) or micrograms per liter (ug/L). Milligrams per liter is a unit expressing the concentration of chemical constituents in solution as weight (milligrams) of sol ute per unit vol ume (liter of water). One thousand micrograms per liter is equivalent to 1 milligram per liter. For concentrations less than $7,000 \mathrm{mg} / \mathrm{L}$, the numerical value is about the same as for concentrations in parts per million. Chemical concentrations in bottom materials is given in units of micrograms per gram (ug/g) or micrograms per kilogram (ug/kg). Both units express concentration on a weight per weight basis.

Water temperature is given in degrees Celsius $\left({ }^{\circ} \mathrm{C}\right)$, which can be converted to degrees Fahrenheit $\left({ }^{\circ} \mathrm{F}\right)$ by the fol lowing equation:

$$
O_{F}=1.8\left({ }^{\circ} \mathrm{C}\right)+32
$$

National Geodetic Vertical Datum of 1929 (NGVD of 1929): A geodetic datum derived from a general adjustment of the first-order level nets of both the United States and Canada, formerly called mean sea level, is referred to as sea level in this report. 


\title{
RECONNAISSANCE OF TOXIC SLBSTANCES IN THE JORDAN RIVER, SALT LAKE COUNTY, UTAH
}

\author{
By Kendal I R. Thompson
}

\section{ABSTRACT}

A reconnaissance of toxic substances in the Jordan River, Salt Lake County, Utah, was made during July 1980 to October 1982 as part of a larger study of the river that included studles of sanitary quallty, dissolved oxygen, and turbidity. Samples for toxic substances were collected at five sites on the Jordan River, at three major tributarles, and at six storm condults.

The toxic substance that most frequently exceeded State standards was total mercury. About 78 percent of the 138 samples for total mercury exceeded the State standard of $0.05 \mathrm{~m} / \mathrm{crogram}$ per 11 iter. Other toxic substances that exceeded State standards were: Ammonia--18 percent of the samples analyzed, cadmium--9 percent, copper--9 percent, zinc--6 percent, and lead--2 percent. One sample for cyanide and one for Iron al so exceeded State standards.

The diversity of toxic substances with concentrations large enough to cause them to be problems increased from the upstream sampling site at the Jordan Narrows to the next two downstream sites at 9000 South and 5800 South Streets. Concentrations of trace el ements in stream-bottom materlals al so Increased in a downstream direction. Substantlal Increases first were observed at 5800 South Street, and they were sustalned throughout the downstream study area.

Iron is transported in the greatest quantity of all the trace el ements studled, with a mean load of 110 pounds per day. Notable loads of barium, boron, lead, and $z$ Inc al so are transported by the river.

$D D D, D D E, D D T, d l e l d r i n$, heptachlor, methoxychlor, $F C B$, and 2,4-D were detected in bottom materlals; and DDE, silvex, and 2,4-D were detected in water samples. Of 112 organic compounds in the Environmental Protection Agency's priority pollutant list, only chloroform was detected in the storm conduits that empty into the Jordan River. Several metals and phenol also were detected in the samples analyzed for priority pollutants. 


\section{INTRODUCT ION}

From July 1980 to October 1982 the US. Geological Survey, in cooperation with the Salt Lake County Division of Flood Control and Water Qual ity, made a study of the qual ity of the Jordan River, Salt Lake County, Utah. Prior to initiation of field work, Federal, State, and local agencies were asked by the U.S. Geological Survey to identify the most serious water-qual ity problems in the Jordan River. As a result of their responses, the study focused on the following subjects: toxic substances (this report), sanitary quality (Thompson, 1984), dissolved oxygen (Stephens, 1984), and turbidity (Weigel, 1984).

The objectives of the study on toxic substances were:

A. Identify selected toxic substances that exceed State standards in the Jordan River and major tributaries.

B. Quantify differences between the dissolved phase and suspended phase of selected toxic substances.

C. Determine selected pesticide concentrations in the Jordan River and major tributaries.

D. Determine concentrations of selected toxic substances in bottom materials of the Jordan River and major tributaries.

E. Identify selected toxic substances that may be transported to the Jordan River as a result of storm runoff from urban areas.

\section{Hydrologic Setting}

The Jordan River originates as outflow from Utah Lake; and it flows north approximately 55 miles before its waters eventual ly reach Farmington Bay, which is part of the Great Salt Lake--a terminal, sal ine lake Two-thirds of the Jordan River basin is within Salt Lake County, and this study is I imited to that area ( $f$ ig. 1 ).

The Jordan River enters Sal t Lake County at the Jordan Narrows, a gap in the Traverse Mountains about 10 miles downstream from Utah Lake (fig. 1). The discharge from Utah Lake is control led by gates or by pumping. The altitude along the river decreases from about 4,470 feet at the Jordan Narrows to about 4,200 feet at the Great Salt Lake. The mean gradient of the Jordan River through Salt Lake County is 6 feet per mile. al though the gradient from the Jordan Narrows to 4200 South Street is 11 feet per mile and from 4200 South Street to the river mouth only 1.9 feet per mile. 


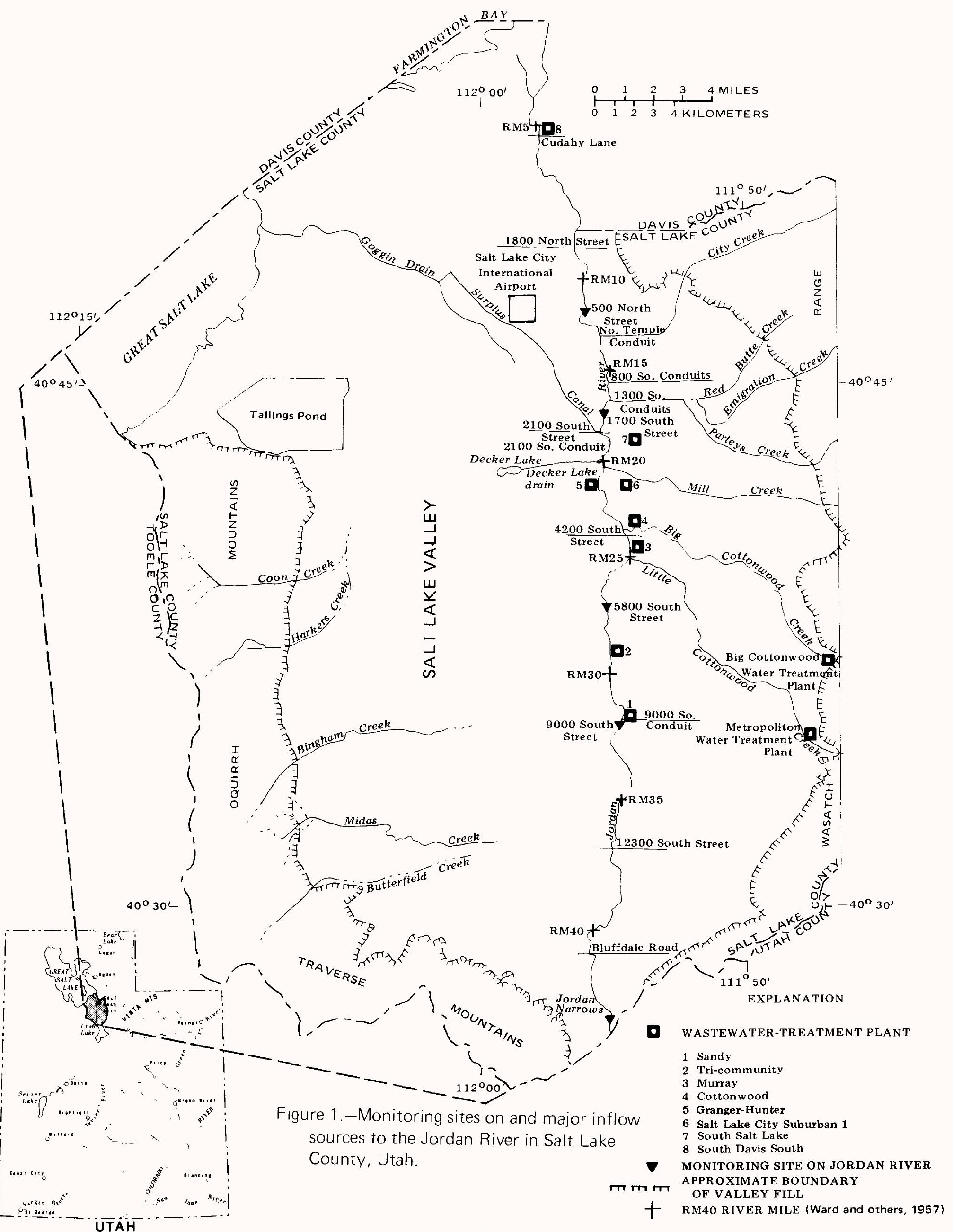


Salt Lake County consists of a central low land, known as the Salt Lake Valley, which includes a large urban area. The valley is bordered by mountains on three sides (fig. 1). The Wasatch Range to the east rises to more than 11,000 feet, the Oquirrh Mountains to the west rise to more than 9,000 feet, and the Traverse Mountains to the south rise to more than 6,000 feet. The population of Sal t Lake County was estimated to be 641,000 as of July 1981 (Marvin Levy, Utah State Health Department, Bureau of Statistical Services, oral commun., 1982), which is about 42 percent of Utah's population. The Jordan River is the primary receiving water for the discharge from this urban area, which includes seven municipal wastewater-treatment plants in Salt Lake County and one plant in Davis County to the north.

The major tributaries to the Jordan River in Salt Lake County originate in the Wasatch Range. Little Cottonwood Creek empties into the river at about 4900 South Street, Big Cottonwood Creek at about 4200 South Street, and Mill Creek at about 3000 South Street. Parleys, Emigration, and Red Butte Creeks are diverted into a storm conduit, which empties into the river at about 1300 South Street. City Creek is diverted into a storm conduit which empties into the river at North Temple Street. Streams on the west side of Salt Lake County typically are diverted by canals or run dry before reaching the river.

During the irrigation season, large quantities of water are diverted from the Jordan River at or near the Jordan Narrows and channeled northward through seven major canals. The major canals east of the Jordan River. which interchange water with tributaries from the Wasatch Range, terminate in smaller canals. Return flows to the Jordan River usually are through streams or storm conduits. Return flows from the canals west of the Jordan River typically reach the river less directly through nonpoint-source runoff. The only major diversion north of 9000 South Street is the Surplus Canal at 2100 South street, a flood-control structure that allows excess water to flow directly to Great Salt Lake.

The climate ranges from semiarid in parts of the Salt Lake Val ley to hum id in higher parts of the Wasatch Range. Precipitation during 1981 near the Salt Lake International Airport was 16.59 inches, which is 1.42 inches greater than the 1928-81 average at this site (National Oceanic and Atmospheric Administration, 1981, p. 4). Precipitation in the valley is generally slight and infrequent during the irrigation season.

\section{Previous Studies}

The Salt Lake County Soil Conservation District (1981) discussed several toxic substances in a report on water quality of agricultural-nonpoint sources. Several pesticides and herbicides were sampled, but no significant problems were found in their study area. 
Way (1977) discussed ammonia, chlorine, and other constituents that affect the Jordan River fishery and safe and projected constituent concentrations. Way (1977, p. 15) recommended that ammonia removal or reduction in concentration (90-percent nitrification) be integrated into future wastewater-treatment processes and that an additional study be made of chlorine in the Jordan River.

Hydroscience, Inc. (1976) discussed ammonia nitrogen, additional nitrogen and phosphorus compounds, dissolved solids, carbonaceous-biochemical-oxygen demand, and coliform bacteria. The report al so states that agricultural return loads contribute significantly to all water-quality constituents investigated except ammonia nitrogen.

Templeton, Linke, and Alsup, and Engineering-Science, Inc. (1974) present a short discussion of toxicity in the Jordan River, and they also report some analytical results. Coburn (1972, p. xi) found that pesticide pollution was increasing south of Salt Lake City. He reported pesticide concentrations that indicate significant use of $0, p-D D T$ and dieldrin.

\section{Sampling Sites}

Water-quality samples and discharge measurements were obtained at five sites on the Jordan River during this study. These sites were at the Jordan Narrows (U.S. Geological Survey station 10167001), 9000 South Street $(10167230), 5800$ South Street (10167300), 1700 South Street (10171000), and 500 North Street $(10172550)$ ( $f$ ig. 1$)$. The five sites generally were sampled monthly and before and during selected rainstorms.

Three major tributaries to the Jordan River al so were sampled near their mouths: Little Cottonwood, Big Cottonwood, and Mill Creeks. In addition, six storm conduits were sampled before and during selected rainstorms: 1300 South Street Conduit--South and North Conduits; 800 South Street Conduit--South, Middle, and North Conduits; and North Temple Conduit.

\section{Methods}

Data for this report were collected using standard methods of the U.S. Geological Survey (Skougstad and others, 1979; and U.S. Geological Survey, 1977). Water samples were col lected using depth-integrating samplers modified for collection of trace metals. The equal-width-increment technique was used to sample the river cross section. Water samples collected during storm runoff from urban areas were composited using a discharge-weighting technique determined from the storm hydrograph at individual sampling sites. Samples for priority pollutants were collected in specially-treated glassware to avoid contact with plastics or metals. Streambed material was sampled with a U.S.BMH-60 bed-material sampler modified for sampling trace metals. In this report a constituent that can pass through a $0.45-\mathrm{micron}$ filter is considered to be dissolved. The dissolved plus the suspended concentration is equal to the total concentration of a constituent. Total recoverable refers to an analytically-determined concentration that may not represent 100 percent of the actual concentration. All analytical work was done by the U.S. Geological 
Survey except that samples collected for analysis of priority pollutants were analyzed at the Utah Biomedical Test Laboratories in Salt Lake City, Utah, and the same samples were analyzed for additional trace elements by Versar Inc., Springfield, Va

\section{State Stream-Use Classes and Assoclated}

\section{Standards for Toxic Substances}

Toxic substances are a widely diversified group of elements and compounds. Many of the constituents referred to in this report as "toxic substances" may occur naturally and may, in some instances, be beneficial in small concentrations. Other constituents are synthetic and, therefore, are evidence of contamination resulting from the activities of man. Both the intended use of the water and the degree of toxicity of individual constituents need to be considered when determining toxicity standards. Numerical standards based on various use classifications have been developed for Utah by the Utah Department of Social Services, Division of Health (1978), and the classification and standards are shown in tables 1-4.

The classification scheme for streams in Utah is show $n$ in table 1. The classification of the Jordan River and three major tributaries is show in table 2. Numerical standards for toxic substances are shown in tables 3 and 4.

\section{TOXIC SLBSTANCES}

In this report, "toxic substance" is used as a general term for a potential ly toxic constituent. Each constituent in a stream segment must be eval uated individually in relation to the use classification of the stream segment; thus, a toxic substance may not be a problem if found in very smal $I$ concentrations.

\section{General Discussion of Toxic Substances That Exceeded}

\section{State Standards in the Jordan River Study Area}

The Jordan River and Little Cottonwood, Big Cottonwood, and MIII Creeks were sampled to determine concentrations of numerous toxic substances. This section of the report addresses only those substances that have been assigned numerical standards by the State. The numerical standards and classes that apply for 17 toxic substances that were actual or potential problems are I isted in table 5, and each toxic substance is discussed in relation to the exceedance of State standards. 
Table 1.--Classification of surface streams in Utah showing protection by type of use

[Utah Department of Social Services, Division of Heal th, 1978, part II, p. 5-6.]

$\mathrm{Cl}$ ass

Use classification

1

$1 \mathrm{~A}$

$1 \mathrm{~B}$

$1 \mathrm{C}$

2

$2 A$

$2 \mathrm{~B}$

3

$3 A$

3B

3C

3D

Protected for use as a raw-water source for domestic water systems.

Protected for domestic purposes without treatment.

Protected for domestic purposes with prior disinfection.

Protected for domestic purposes with prior treatment by standard complete treatment processes as required by the Utah Division of Heal th.

Protected for instream-recreational use and esthetics.

Protected for recreational bathing (swimming).

Protected for boating, waterskiing, and similar uses, excluding recreational bathing (swimming).

Protected for instream use by beneficial-aquatic wildlife.

Protected for cold-water species of game $f i$ sh and other coldwater aquatic life, including the necessary aquatic organisms in their food chain.

Protected for warm-water species of game fish and other warmwater aquatic life, including the necessary aquatic organisms in their food chain.

Protected for nongame $f$ ish and other aquatic life, including the necessary aquatic organisms in their food chain. Standards for this class will be determined on a case-by-case basis. (See table 4.)

Protected for water fow l, shorebirds, and other water-oriented wildlife, including the necessary aquatic organisms in their food chain.

4

Protected for agricultural uses including irrigation of crops and stock watering.

5

Protected for industrial uses including cooling, boiler make-up and others with potential for human contact or exposure. Standards for this class will be determined on a case-by-case basis.

6

Protected for uses of water not generally suitable for the uses described above. Standards for this class will be determined on a case-by-case basis. 
Table 2.--Classification of the Jordan River and three major tributaries in Sal t Lake County

[Utah Department of Social Services, Division of Heal th, 1978, Part II, P. 13-14.]

Jordan River from the Jordan Narrows to the confluence with Little Cottonwood Creek

Jordan River from the confluence with Little Cottonwood Creek to North Temple Street

Jordan River from North Temple Street to Farmington Bay

Little Cottonwood Creek from confluence with the Jordan River to Metropol itan Water-Treatment PIant

Big Cottonwood Creek from confluence with the Jordan River to Big Cottonwood Water-Treatment Plant

Mill Creek from confluence with the Jordan River to headwaters
$2 B, 3 A, 4$

$2 B, 3 B, 4$

$2 B, 3 C, 3 D, 4$

$3 A, 4$

$2 B, 3 A, 4$

$2 B, 3 A, 4$ 
Table 3.--Numerlcal standards for protection of beneficlal uses of water in Utah

[Adapted from Utah Department of Soclal Services, Divislon of Health, 1978, Part II, p. 8; Water-qual ity standards pertalning to water-use Classes for Aquatic Wildilfe (3C), Industry (5), and Speclal $(6)$ categorles will be determined on a case-by-case basis.]

\begin{tabular}{|c|c|c|c|c|c|c|c|c|c|}
\hline \multirow{3}{*}{ Constl tuent } & \multicolumn{9}{|c|}{ Water-Use $\mathrm{Cl}$ asses } \\
\hline & \multicolumn{3}{|c|}{ Domestic source } & \multicolumn{2}{|c|}{$\begin{array}{c}\text { Recreation and } \\
\text { esthetlics }\end{array}$} & \multicolumn{3}{|c|}{ Aquatic wild I fe } & \multirow{2}{*}{$\begin{array}{c}\text { Agr Icul ture } \\
4\end{array}$} \\
\hline & $1 \mathrm{~A}$ & $1 \mathrm{~B}$ & ic & $2 \mathrm{~A}$ & $2 B$ & $3 A$ & 3B & 30 & \\
\hline \multicolumn{10}{|l|}{ Chemlcal (Maximum, milligrams per liter) } \\
\hline Arsenic, dissolved & 0.05 & 0.05 & 0.05 & * & * & * & * & * & 0.1 \\
\hline Barium, dissolved & 1 & 1 & 1 & * & * & * & * & * & * \\
\hline Boron, dissolved & * & * & * & * & * & $*$ & * & * & .75 \\
\hline Cadmium, dissolved & .010 & .010 & .010 & * & * & ${ }^{1} 0.0004$ & ${ }^{1} 0.004$ & * & .01 \\
\hline Copper, dissolved & * & * & * & * & * & .01 & .01 & * & .2 \\
\hline Cyanlde & * & * & * & * & * & .005 & .005 & * & * \\
\hline Iron, dissolved & * & * & * & * & * & 1.0 & 1.0 & 1.0 & * \\
\hline Lead, dissolved & .05 & .05 & .05 & * & * & .05 & .05 & * & .1 \\
\hline Mercury, total & .002 & .002 & .002 & * & * & .00005 & .00005 & .00005 & * \\
\hline Selenlum, dissolved & .01 & .01 & .01 & * & * & .05 & .05 & * & .05 \\
\hline SIlver, dissolved & .05 & .05 & .05 & * & * & .01 & .01 & * & * \\
\hline Zinc, dissolved & * & * & * & * & * & .05 & .05 & * & * \\
\hline Armonla as nltrogen (unlonized) & * & * & * & * & * & .02 & .02 & * & * \\
\hline Phenol & * & * & * & * & * & .01 & .01 & * & * \\
\hline Endrin & .2 & .2 & .2 & * & * & .004 & .004 & .004 & * \\
\hline Lindane & 4 & 4 & 4 & * & * & .01 & .01 & .01 & * \\
\hline Methaxychlor & 100 & 100 & 100 & * & * & .03 & .03 & .03 & * \\
\hline Toxaphene & 5 & 5 & 5 & * & * & .005 & .005 & .005 & * \\
\hline 2, 4-D herblclde & 100 & 100 & 100 & * & * & * & * & * & * \\
\hline $2,4,5-T P$ herblclde & 10 & 10 & 10 & * & * & * & * & * & * \\
\hline
\end{tabular}

* Insufficlent evldence to warrant the establishment of numerical standard. LImIts assigned on case-by-case basis. LImIt shail be increased three-fold if $\mathrm{CaCO}_{3}$ hardness in water exceeds 150 mlliligrams per liter. 
Table 4.--Numerical standards pertaining to toxic substances for protection of $\mathrm{Cl}$ ass $3 \mathrm{C}$ water use in the Jordan River from Farmington Bay to North

Temple Street in Salt Lake City

[Adapted from Utah Department of Social Services, Division of Health, 1978, Fart 11, p. 30.]

Constituent Standard

Chemical (Maximum, milligrams per liter)

Cadmium, dissol ved

Chromium, dissolved

Copper, dissol ved

Cyanide

Iron, dissolved

Lead, dissolved

Mercury, total

Selenium, dissolved

Silver, dissolved

Zinc, dissolved

Phenol

0.004

. 1

.01

.005

1.0

.05

.0005

.05

.01

.05

.01

Pesticides (Maximum, micrograms per liter)

Endrin

.004

Lindane

.01

Methoxychl or

Toxaphene

.03

.005 
Table 5.--Selected toxic substances in the Jordan River and three tributaries related to use classes and state standards

Use classes and State standards: See tables 1 and 3.

\begin{tabular}{|c|c|c|c|c|c|c|c|}
\hline \multirow[b]{2}{*}{ Constituent } & \multirow[b]{2}{*}{ Use classes } & \multirow[b]{2}{*}{$\begin{array}{c}\text { State } \\
\text { standards } \\
(u g / L)\end{array}$} & \multirow[b]{2}{*}{$\begin{array}{l}\text { Total number } \\
\text { of samples }\end{array}$} & \multicolumn{4}{|c|}{$\begin{array}{l}\text { Statistics for sample concentrations that } \\
\text { exceeded state standards }\end{array}$} \\
\hline & & & & $\begin{array}{l}\text { Number of } \\
\text { samples }\end{array}$ & $\begin{array}{l}\text { Mean } \\
(\mathrm{ug} / \mathrm{L})\end{array}$ & $\begin{array}{l}\text { Standard } \\
\text { deviation } \\
\text { (ug/L) }\end{array}$ & $\begin{array}{c}\text { Maximum } \\
\text { concentration } \\
(\mathrm{ug} / \mathrm{L})\end{array}$ \\
\hline Anmonia & $3 A, 3 B$ & 20 & 85 & 15 & $\left({ }^{l}\right)$ & $\left({ }^{1}\right)$ & $\left({ }^{l}\right)$ \\
\hline Arsenic & 4 & 100 & 16 & 0 & - & - & - \\
\hline Boron & 4 & 750 & 27 & 0 & - & - & - \\
\hline Cadnium & $\begin{array}{l}3 \mathrm{~A} \\
3 \mathrm{~B}, 3 \mathrm{C} \\
4\end{array}$ & $\begin{array}{l}0.4 \\
4 \\
10\end{array}$ & 228 & 20 & 3.1 & 2.48 & 10 \\
\hline Chromium & $3 \mathrm{~A}, 3 \mathrm{~B}, 3 \mathrm{C}, 3 \mathrm{D}, 4$ & 100 & 131 & 0 & - & - & -- \\
\hline Copper & $\begin{array}{l}3 \mathrm{~A}, 3 \mathrm{~B}, 3 \mathrm{C} \\
4\end{array}$ & $\begin{array}{r}10 \\
200\end{array}$ & 228 & 20 & 15.4 & 5.00 & 28 \\
\hline Cyanide & $3 A, 3 B, 3 C$ & 5 & 45 & 1 & - & - & 10 \\
\hline Iron & $3 A, 3 B, 3 C, 3 D$ & 1,000 & 213 & 1 & - & - & 1,100 \\
\hline Lead & $\begin{array}{l}3 \mathrm{~A}, 3 \mathrm{~B}, 3 \mathrm{C} \\
4\end{array}$ & $\begin{array}{r}50 \\
100\end{array}$ & 213 & 4 & 64.5 & 13.28 & 80 \\
\hline Mercury & $3 A, 3 B, 3 C, 3 D$ & 0.05 & 138 & 107 & .17 & .14 & 1.2 \\
\hline Phenol & $3 A, 3 B, 3 C$ & 10 & 25 & 0 & - & - & -- \\
\hline Selenium & $3 \mathrm{~A}, 3 \mathrm{~B}, 3 \mathrm{C}, 4$ & 50 & 38 & 0 & - & - & - \\
\hline Silver & $3 \mathrm{~A}, 3 \mathrm{~B}, 3 \mathrm{C}$ & 10 & 38 & 0 & - & - & - \\
\hline Zinc & $3 A, 3 B, 3 C$ & 50 & 220 & 13 & 103 & 66.37 & 280 \\
\hline Endrin & $3 A, 3 B, 3 C, 3 D$ & 4 & 27 & 0 & - & -- & - \\
\hline Lindane & $3 \mathrm{~A}, 3 \mathrm{~B}, 3 \mathrm{C}, 3 \mathrm{D}$ & 10 & 6 & 0 & - & - & -- \\
\hline Toxaphene & $3 A, 3 B, 3 C, 3 D$ & 5 & 6 & 0 & - & -- & -- \\
\hline
\end{tabular}

1 Not applicable. Concentrations of ammonia that exceeded State standards are determined from a table using temperature, $\mathrm{pH}$, and concentrations of ammonia nitrogen which produce an unionized ammonia concentration of $20 \mathrm{ug} / \mathrm{L}$ as N. (See Willingham, 1976, p. Al9-73.) 
Mercury.--The toxic substance that most frequently exceeded State standards was total mercury. Of the 138 analyses for total mercury, 107 (78 percent) exceeded the state standard of $0.05 \mathrm{microgram}$ per 1 iter. The analytical detection limit for mercury is $0.1 \mathrm{microgram}$ per liter, which is double the standard. Concentrations of total mercury between the standard and the detection limit are unknown. Some samples listed as undetectable probably were within this range, thus the number of samples that exceeded the state standard may be underestimated. The maximum mercury concentration was 1.2 micrograms per liter, which is 24 times greater than the State standard. The mean of the mercury concentrations that exceeded the State standard was 0.17 microgram per liter, which is more than three times greater than the State standard. The distribution of the total mercury concentrations is shown bel ow:

\begin{tabular}{|c|c|c|c|c|c|c|c|}
\hline \multirow{2}{*}{$\begin{array}{c}\text { Number of } \\
\text { samples }\end{array}$} & \multirow{2}{*}{$\begin{array}{c}\text { Analytical } \\
\text { detection l imit } \\
(u g / L)\end{array}$} & \multicolumn{6}{|c|}{ Percentiles } \\
\hline & & 5 & 25 & 50 & 75 & 95 & 99 \\
\hline 138 & 0.1 & $<0.1$ & 0.1 & 0.1 & 0.2 & 0.3 & 1.08 \\
\hline
\end{tabular}

1 Percent of samples in which the concentration was equal to or less than the value shown.

Mercury is a heavy, silver-white, poisonous, metall ic element. It is the only metal occurring as a liquid at room temperature. Mercury al so occurs as univalent and divalent ions and compounds. Mercury is used in numerous types of electrical apparatus, control devices, thermometers, barometers, and vapor lamps. Other possible sources of mercury are industrial and mining wastes. Organic mercury compounds are found in pesticides, particularly in fungicides; and anaerobic bacteria in alkal ine waters produce methylated mercuric compounds, which can be concentrated in the fatty tissue of $f$ ish at more than 100 times the water concentration.

Ammonia-Nitrogen.-- of the 85 analyses for ammonia-nitrogen, 15 (18 percent) exceeded the State standard of 20 micrograms per liter of unionized ammonia. Ammonia is present predom inately as $\mathrm{NH}_{4}^{+}$(at normal $\mathrm{pH}^{+} \mathrm{s}$ ). The concentration of unionized ammonia $\left(\mathrm{NH}_{3}\right)$ which is toxic to aquatic organisms, is a function of the total dissolved ammonia-nitrogen concentration, water temperature, and $\mathrm{pH}$ Ammonia is a pungent, colorless, gaseous, alkal ine compound of nitrogen and hydrogen which is readily soluble in water. It is a normal biological degradation product of nitrogenous organic matter, and it is very common in effluents from wastewater-treatment plants. Unionized ammonia is toxic to fish, but its toxicity varies with the temperature and $\mathrm{pH}$ of the water. 
Cadmium.--Of the 228 analyses for dissolved cadmium, 20 ( 9 percent) exceeded the State standards. Cadmium is nonessential and nonbeneficial to any type of 1 ife and has a large toxic potential (U.S. Environmental Protection Agency, 1976, p. 27). The mean of the cadmium concentrations that exceeded the State standard was 3.1 micrograms per liter, and the maximum concentration was 10 micrograms per liter. Cadmium is a soft white metal similar to zinc and lead. Cadmium occurs in nature chiefly as a sulfide salt. Sources of cadmium are industrial discharge, pigment works, textile and chemical industries, mining waste, and metal electroplating.

Copper.-- Of the 228 analyses for dissolved copper, 20 (9 percent) exceeded the State standard of $10 \mathrm{micrograms}$ per 1 iter. The mean of the copper concentrations that exceeded the state standard was $15.4 \mathrm{micrograms}$ per liter, and the maximum concentration was 28 micrograms per liter. Copper is an essential trace element for the propagation of plants, and it also is required in animal metabol ism. However, large concentrations of copper may be toxic to aquatic life. Copper occurs as a natural metal in cuprite, in sulfide, oxide, and carbonate ores. Oxides and sulfates of copper are used for pesticides, algacides, and fungicides, and copper often is added to paints and wood perservatives.

Zinc.--Of the 220 analyses for dissolved $z$ inc, 13 ( 6 percent) exceeded the State standard of $50 \mathrm{micrograms}$ per liter. The mean of the zinc concentrations that exceeded the State standard was 103 micrograms per liter. The maximum concentration was 280 micrograms per liter. which is 5.6 times greater than the state standard. Zinc usually is found in nature as a sulfide, and it often is associated with the sulfides of other metals. Zinc is used in galvanizing and the preparation of al loys for dye casting, and sources of zinc include industrial waste, metal plating, and sewage sludge.

Lead.--Of the 213 analyses for dissolved lead, 4 (2 percent) exceeded the State standard of $50 \mathrm{micrograms}$ per liter. The mean of the concentrations that exceeded the State standard $w$ as 64.5 micrograms per 1 iter, and the maximum concentration was $80 \mathrm{micrograms}$ per liter. Lead is a soft, bivalent or tetravalent metallic el ement. Lead enters the aquatic environment through precipitation, atmospheric fallout, municipal and industrial wastes, leaching of soil, and deposits from streets and other surfaces that may be washed into a stream.

Cyanide.--Of the 45 analyses for total cyanide, only 1 exceeded the State standard of $5 \mathrm{micrograms}$ per liter. This sample had a concentration of 10 micrograms per liter. Cyanide commonly is used in industry, especially for metal cleaning and electroplating, and it also is used as a fumigant.

Iron.--Of the 213 analyses for dissolved iron, only 1 exceeded the State standard of 1,000 micrograms per liter. This sample had an iron concentration of 1,100 micrograms per liter. Iron is the fourth most abundant el ement (by weight) in the Earth's crust. Iron is an essential trace element for both plants and animals, but in larger concentrations it may harm aquatic life. 
Arsenic, chromium, phenol, selenium, silver, boron, endrin, lindane, and toxaphene.--Did not exceed state standards in samples collected from the Jordan River and its three major tributaries.

\section{Distribution of Toxic Substances in the Jordan}

\section{River Study Area}

As the Jordan River flows through the study area, numerous factors affect the quality of its water. Several diversions remove water from the river for irrigation and flood control, thus reducing the river's capacity for dilution. The river al so receives inflow from numerous tributaries, seven wastewatertreatment plants, numerous storm conduits, the ground-water system, irrigation-return flow, and other sources. All of these factors contribute to the dynamic system that determines the quality of the Jordan River.

\section{Toxic Substances that Exceeded State Standards}

The diversity of toxic substances with concentrations large enough to cause them to be problems increases from the Jordan Narrows to the next downstream sampling site at 9000 South street. Mercury and zinc exceeded the State standard at the Jordan Narrows (table 6). Cadmium, copper, lead, mercury. and zinc exceeded the State standard at 9000 South Street. The diversity of toxic substances with problem concentrations increased again at the next downstream site at 5800 South street where ammonia, cadmium, copper, cy anide, lead, mercury, and $z$ inc exceeded the State standard. At the next downstream sampling site, the diversity of toxic substances with problem concentrations was reduced. Only ammonia, copper, mercury, and zinc concentrations exceeded the State standard at 1700 South Street. At 500 North Street, the sampling site farthest downstream, problem concentrations were observed for copper, lead, mercury, and zinc. Problem concentrations of ammonia were found at 1700 South and 5800 South Streets, a reach of the river to which most of the wastewater-treatment plants discharge (fig. 1). Problem concentrations were not found at 500 North Street, thus wastewater-treatment plants are the probable cause of the problem ammonia concentrations.

Problem concentrations of mercury and $z$ inc were found at al l sampling sites on the Jordan River. Problem concentrations of copper were found at all sites except the Jordan Narrows, and problem concentrations of lead were found at three of the five sites on the Jordan River.

The three major tributaries to the Jordan River were sampled near their confluence with the river. Problem concentrations of ammonia, cadmium, copper, iron, mercury, and zinc were detected in samples from Little Cottonwood Creek (table 6). Problem concentrations of ammonia, cadmium, copper, mercury, and zinc were detected in samples from Big Cottonwood Creek. Problem concentrations of cadmium, copper, and mercury were detected in samples from Mill Creek. 
Table 6.--Toxic substances that exceeded State standards in the Jordan River and three major tributaries

Number of samples: -- Indicates that no sample exceeded State standards.

First I ine--Number of samples that exceeded State standards.

Second I ine--Number of above samples collected during storm runoff.

Third I ine--Total number of samples.

\begin{tabular}{|c|c|c|c|c|c|c|c|c|}
\hline Location & $\begin{array}{l}\text { Ammonia, } \\
\text { unionized }\end{array}$ & $\begin{array}{l}\text { Cadml um, } \\
\text { dissol ved }\end{array}$ & $\begin{array}{l}\text { Copper, } \\
\text { dissol ved }\end{array}$ & $\begin{array}{l}\text { Cyanide, } \\
\text { total }\end{array}$ & $\begin{array}{l}\text { Iron, } \\
\text { dissolved }\end{array}$ & $\begin{array}{l}\text { Lead, } \\
\text { dissolved }\end{array}$ & $\begin{array}{l}\text { Mercury, } \\
\text { total }\end{array}$ & $\begin{array}{l}\text { Zinc, } \\
\text { dissolved }\end{array}$ \\
\hline \multicolumn{9}{|c|}{$\begin{array}{c}\text { Number of samples } \\
\text { Jordan River }\end{array}$} \\
\hline Jordan Narrows & $\frac{-}{16}$ & $\overline{--}$ & $\overline{--}$ & -- & $\overline{--}$ & $=$ & $\begin{array}{r}15 \\
2 \\
21\end{array}$ & $\begin{array}{r}1 \\
0 \\
28\end{array}$ \\
\hline 9000 South Street & $\overline{--}$ & $\begin{array}{r}7 \\
3 \\
33\end{array}$ & $\begin{array}{r}1 \\
0 \\
33\end{array}$ & -- & $\overline{30}$ & $\begin{array}{r}2 \\
0 \\
30\end{array}$ & $\begin{array}{r}14 \\
2 \\
17\end{array}$ & $\begin{array}{r}1 \\
0 \\
25\end{array}$ \\
\hline 5800 South Street & $\begin{array}{r}7 \\
0 \\
17\end{array}$ & $\begin{array}{r}5 \\
2 \\
33\end{array}$ & $\begin{array}{r}5 \\
1 \\
33\end{array}$ & $\begin{array}{r}1 \\
0 \\
24\end{array}$ & $\overline{30}$ & $\begin{array}{r}1 \\
0 \\
30\end{array}$ & $\begin{array}{r}14 \\
3 \\
22\end{array}$ & $\begin{array}{r}2 \\
1 \\
33\end{array}$ \\
\hline 1700 South Street & $\begin{array}{r}6 \\
0 \\
16\end{array}$ & $\overline{43}$ & $\begin{array}{r}4 \\
2 \\
43\end{array}$ & -- & $\overline{--}$ & $\overline{40}$ & $\begin{array}{r}27 \\
3 \\
31\end{array}$ & $\begin{array}{r}3 \\
0 \\
43\end{array}$ \\
\hline 500 North Street & $\overline{--}$ & $\overline{--}$ & $\begin{array}{r}2 \\
1 \\
36\end{array}$ & -- & $\overline{33}$ & $\begin{array}{r}1 \\
1 \\
33\end{array}$ & $\begin{array}{r}18 \\
4 \\
21\end{array}$ & $\begin{array}{r}4 \\
1 \\
36\end{array}$ \\
\hline \multicolumn{9}{|c|}{ Tributaries } \\
\hline $\begin{array}{c}\text { Little Cottonwood } \\
\text { Creek }\end{array}$ & $\begin{array}{l}1 \\
0 \\
2\end{array}$ & $\begin{array}{r}4 \\
3 \\
21\end{array}$ & $\begin{array}{r}5 \\
4 \\
21\end{array}$ & $\overline{--}$ & $\begin{array}{r}1 \\
1 \\
21\end{array}$ & $\overline{--}$ & $\begin{array}{l}8 \\
4 \\
9\end{array}$ & $\begin{array}{r}1 \\
1 \\
21\end{array}$ \\
\hline $\begin{array}{l}\text { Big Cottonwood } \\
\text { Creek }\end{array}$ & $\begin{array}{l}1 \\
0 \\
1\end{array}$ & $\begin{array}{r}2 \\
1 \\
17\end{array}$ & $\begin{array}{r}2 \\
1 \\
17\end{array}$ & -- & $\overline{--}$ & $\overline{--}$ & $\begin{array}{l}5 \\
2 \\
9\end{array}$ & $\begin{array}{r}1 \\
1 \\
17\end{array}$ \\
\hline Mill Creek & -- & $\begin{array}{r}2 \\
2 \\
17\end{array}$ & $\begin{array}{r}1 \\
1 \\
17\end{array}$ & $\begin{array}{c}-- \\
-- \\
0\end{array}$ & $\frac{--}{17}$ & $\frac{-}{17}$ & $\begin{array}{l}6 \\
4 \\
8\end{array}$ & $\begin{array}{l}-- \\
-- \\
17\end{array}$ \\
\hline
\end{tabular}




\section{Organic Toxic Substances}

Water samples obtained at the five sites on the Jordan River and at the three major tributarles were analyzed for 19 pesticides and total polychlorinated biphenyls (PCB). Bottom-material samples from the same sites were analyzed for 17 pesticides and total PCB. The water and bottom-material samples were collected during August 1981 and August 1982, and the compounds for which analyses were made are I isted below.

\section{Water Samples}

$\begin{array}{lll}\text { Aldrin } & \text { Chlordane } & \text { DDD } \\ \text { DDE } & \text { DDT } & \text { Dieldrin } \\ \text { Endosulfan } & \text { Endrin } & \text { Heptachlor } \\ \text { Heptachl or epoxide } & \text { Lindäne } & \text { Mirex } \\ \text { Napthalenes, polychlorinated } & \text { PCB } & \text { Silvex } \\ \text { Perthane } & 2,4-D & 2,4-D P\end{array}$

Toxaphene

$2,4,5-T$

\section{Bottom-Material Samples}

$\begin{array}{lll}\text { Aldrin } & \text { DDD } & \text { DDE } \\ \text { DDT } & \text { Dieldrin } & \text { Endosulfan } \\ \text { Endrin } & \text { Heptachlor } & \text { Heptachlor epoxide } \\ \text { Lindane } & \text { Methoxychlor } & \text { Perthane } \\ \text { PCB } & \text { Silvex } & \text { Toxaphene } \\ 2,4-D & 2,4-D P & 2,4,5-T\end{array}$

Only 11 of the 20 compounds were detected at least once in either water or bottom-material samples (table 7). PCB in bottom materials was detected most frequently. The largest concentrations of PCB were detected at the Jordan Narrows, and were substantially greater than the concentrations detected at all other sites.

The largest pesticide concentration was for 2,4-D which was 320 micrograms per kilogram in a bottom-material sample from Big Cottonwood Creek. DDD, DDE, dieldrin, and methoxychlor were detected frequently in bottom materials. Few pesticides were detected in water samples. DDE was detected once, Silvex three times, and 2,4-D four times in water samples. 
Table 7.--Concentrations of pesticides and $\mathrm{POB}^{\prime} \mathrm{s}$ detected in the Jordan River and three major trlbutarles

Organic compound: Total in bottom materials, except as noted.

Concentration: ND indicates not detected.

First I ine--Samples collected August 1981.

Second I ine--Samples col lected August 1982.

\begin{tabular}{|c|c|c|c|c|c|c|c|c|}
\hline \multirow{3}{*}{$\begin{array}{l}\text { Organlc } \\
\text { compound }\end{array}$} & \multicolumn{5}{|c|}{ Jordan River } & \multicolumn{3}{|c|}{ Tributaries } \\
\hline & $\begin{array}{l}\text { Jordan } \\
\text { Narrows }\end{array}$ & $\begin{array}{l}9000 \\
\text { South } \\
\text { Street }\end{array}$ & $\begin{array}{l}5800 \\
\text { South } \\
\text { Street }\end{array}$ & $\begin{array}{l}1700 \\
\text { South } \\
\text { Street }\end{array}$ & $\begin{array}{l}500 \\
\text { North } \\
\text { Street }\end{array}$ & $\begin{array}{c}\text { Lit+le } \\
\text { Cottonwood } \\
\text { Creek }\end{array}$ & $\begin{array}{c}\text { Big } \\
\text { Cottonwood } \\
\text { Creek }\end{array}$ & $\begin{array}{l}\text { Mill } \\
\text { Creek }\end{array}$ \\
\hline & \multicolumn{8}{|c|}{ Concentration, in ug $/ \mathrm{kg}$ except as noted } \\
\hline DDD & $\begin{array}{l}\text { ND } \\
\text { ND }\end{array}$ & $\overline{0.2}$ & $\begin{array}{l}\mathrm{ND} \\
0.4\end{array}$ & $\begin{array}{l}0.3 \\
1.0\end{array}$ & $\begin{array}{l}3.8 \\
4.9\end{array}$ & $\begin{array}{l}0.2 \\
\mathrm{ND}\end{array}$ & $\begin{array}{l}3.2 \\
1.0\end{array}$ & 35 \\
\hline DDE & $\begin{array}{l}\text { ND } \\
\text { ND }\end{array}$ &.- & $\begin{array}{r}.3 \\
1.4\end{array}$ & $\begin{array}{l}.2 \\
.8\end{array}$ & $\begin{array}{l}3.3 \\
2.0\end{array}$ & $\begin{array}{l}.2 \\
.4\end{array}$ & $\begin{array}{l}2.0 \\
N D\end{array}$ & $\overline{14}$ \\
\hline $\begin{array}{l}\text { DDE, total } \\
\text { (ug/L) } \\
\text { (in water) }\end{array}$ & $\stackrel{\text { ND }}{-}$ & -- & $\begin{array}{l}\text { ND } \\
--\end{array}$ & $\underset{N D}{.01}$ & $\stackrel{N D}{--}$ & $\begin{array}{l}\text { ND } \\
--\end{array}$ & $\begin{array}{l}\text { ND } \\
--\end{array}$ & -- \\
\hline DDT & $\begin{array}{l}\text { ND } \\
\text { ND }\end{array}$ & $\overline{\text { ND }}$ & $\begin{array}{l}\mathrm{ND} \\
\mathrm{ND}\end{array}$ & $\begin{array}{l}\mathrm{ND} \\
.2\end{array}$ & $\begin{array}{r}1.4 \\
.5\end{array}$ & $\begin{array}{l}\text { ND } \\
\text { ND }\end{array}$ & $\begin{array}{l}\text { ND } \\
.5\end{array}$ & $\overline{N D}$ \\
\hline Dieldrin & $\begin{array}{l}\text { ND } \\
\text { ND }\end{array}$ & $\overline{\mathrm{ND}}$ & $\begin{array}{l}\mathrm{ND} \\
.2\end{array}$ & $\dot{N D}^{1}$ & $\begin{array}{r}.4 \\
1.8\end{array}$ & $\begin{array}{l}.1 \\
.2\end{array}$ & $\begin{array}{r}.9 \\
1.0\end{array}$ & -- \\
\hline Heptachlor & $\begin{array}{l}\text { ND } \\
\text { ND }\end{array}$ & $\overline{\mathrm{ND}}$ & $\begin{array}{l}\text { ND } \\
\text { ND }\end{array}$ & ND & $\begin{array}{l}\mathrm{ND} \\
.3\end{array}$ & $\begin{array}{l}\mathrm{ND} \\
\mathrm{ND}\end{array}$ & $\begin{array}{l}\text { ND } \\
.1\end{array}$ & $\overline{N D}$ \\
\hline Methoxychlor & $-\overline{80}$ & $\overline{7.4}$ & $\begin{array}{l}5.2 \\
8.8\end{array}$ & $\overline{5.2}$ & 12 & $\overline{7.5}$ & 13 & $\overline{1.1}$ \\
\hline $\mathrm{PCB}$ & $\begin{array}{l}320 \\
230\end{array}$ & -- & $\begin{array}{l}2 \\
1\end{array}$ & $\begin{array}{l}6 \\
6\end{array}$ & $\begin{array}{l}14 \\
37\end{array}$ & $\begin{array}{l}2 \\
4\end{array}$ & $\begin{array}{l}17 \\
26\end{array}$ & 50 \\
\hline $\begin{array}{l}\text { Silvex, total } \\
\text { (ug/L) } \\
\text { (In water) }\end{array}$ & $\stackrel{\text { ND }}{--}$ & $\begin{array}{l}\text { ND } \\
--\end{array}$ & $\begin{array}{l}\text { ND } \\
\text { ND }\end{array}$ & -01 & $\therefore$ & ND & $\therefore .02$ & $\overline{\mathrm{ND}}$ \\
\hline $2,4-D$ & $\begin{array}{l}\text { ND } \\
\text { ND }\end{array}$ & $\overline{\text { ND }}$ & $\begin{array}{l}\mathrm{ND} \\
\mathrm{ND}\end{array}$ & -.06 & $\therefore$ & $\begin{array}{l}\text { ND } \\
\text { ND }\end{array}$ & $\begin{array}{l}\mathrm{ND} \\
320^{\circ}\end{array}$ & $=$ \\
\hline $\begin{array}{l}2,4-D \text {, total } \\
\text { (ug/L) } \\
\text { (In water) }\end{array}$ & -.02 & -- & $\therefore$ & $=$ & $=$ &.$_{N D}^{.06}$ & $\therefore$ & $\overline{\text { ND }}$ \\
\hline
\end{tabular}


Water samples from the five sites on the Jordan River were collected during June and August 1982 for analysis of 27 volatile-organic compounds. Only 1 of the 27 volatile compounds was detected. Tetrachloroethy lene was detected in the Jordan River at 500 North Street in a concentration of 5 micrograms per liter in June and in a concentration of 1 microgram per liter in August. A list of the 27 volatile compounds is shown below:

Chl oroethy lene
Carbon tetrachl oride
Chl oroethane
Dichlorodifl uoromethane
Methy lenechl or ide
Trichl oroethyl ene
1,1-dichloroethy lene
$1,1,2-t r i c h l o r o e t h a n e$
$1,2-$ dichloropropane
Benzene
Chlorobenzene
Chloroform
Ethy lbenzene
Tetrachloroethylene

Chl oroethy lene

Carbon tetrachloride

Chl oroethane

Dichl orodifl uor omethane

Methy lenech l or ide

Trichloroethylene

$1,1-$ dichl oroethy lene

$1,1,2-\operatorname{trichl}$ oroethane

1,2-dichloropropane

Benzene

Chl orobenzene

Chl or of orm

Tetrachl oroethylene
Trich l orof I uoromethane

1,1-dichl oroethane

$1,1,2,2$-tetrach l or oethane

1,3-dichl oropropane

Bromoform

Chl orodibromomethane

Dichl orobromomethane

Methy I bromide

Tol uene

Vinyl chloride

$1,1,1-\operatorname{tr} i \mathrm{chl}$ oroethane

1,2-dichl oroethane

2-chloroethyl vinyl ether

Trace Elements in Stream-Bottom Materials

Samples of stream-bottom materials from the Jordan River and the three major tributaries were analyzed for 11 trace elements, each of which could be considered as a toxic substance if present in large enough quantities. The trace elements were: Arsenic, beryllium, cadmium, chromium, cobalt, copper, lead, mercury, selenium, silver, and zinc. With the exception of beryllium, all these trace elements were detected one or more times (table 8). Copper, lead, and zinc had the largest concentrations. Trace-element concentrations in the bottom materials in the Jordan River increased in a downstream direction. Substantial increases first were observed at 5800 South Street, and they were sustained throughout the remainder of the downstream segment of the study area.

Mean concentrations of arsenic, cadmium, chromium, and mercury in bottom materials were about twice as large at three downstream sites on the Jordan River ( 5800 South, 1700 South, and 500 North Streets) as they were at two upstream sites (Jordan Narrows and 9000 South Street). Mean copper and zinc concentrations were about six times larger and mean lead concentrations were about eight times larger at the three downstream sites than they were at the two upstream sites. The larger concentrations identified in the downstream reach of the river probably are due to runoff from urban areas and the significant inflow from wastewater-treatment plants. 
Table 8.--Concentrations of seiected trace elements in bottom materials

in the Jordan River and three major tributaries

\begin{abstract}
Concentrations:
First II ne--Samples collected during September 1980.

Second I ine--Samples collected during August 1981.

Third i ine--Samples collected during August 1982.
\end{abstract}

\begin{tabular}{|c|c|c|c|c|c|c|c|c|c|c|c|}
\hline \multirow[b]{2}{*}{ Location } & \multicolumn{11}{|c|}{ Concentrations (micrograms per gram) } \\
\hline & Arsenic & BerylIIum & Cadmi um & Chromium & Cobalt & Copper & Lead & Mercury & Selenium & Silver & Zinc \\
\hline \multicolumn{12}{|c|}{ Jordan River } \\
\hline \multirow[t]{3}{*}{ Jordan Narrows } & -- & -- & -- & -- & -- & -- & -- & - & -- & -- & -- \\
\hline & 6 & $<1$ & 1 & 3 & -- & 7 & 30 & 0.02 & $<1$ & -- & 35 \\
\hline & 6 & $<1$ & 1 & 2 & -- & 10 & 40 & .03 & $<1$ & 1 & 47 \\
\hline \multirow[t]{3}{*}{9000 South street } & -- & -- & -- & -- & -- & -- & -- & - & -- & -- & -- \\
\hline & -- & -- & 1 & 3 & $<5$ & 12 & 10 & - & $<1$ & -- & 23 \\
\hline & 6 & $<1$ & $<1$ & 2 & -- & 11 & 20 & .03 & $<1$ & 1 & 25 \\
\hline \multirow[t]{3}{*}{5800 South Street } & -- & -- & -- & -- & -- & -- & -- & - & -- & -- & -- \\
\hline & 17 & $<1$ & 1 & 3 & -- & 90 & 200 & .03 & $<1$ & -- & 140 \\
\hline & 19 & $<1$ & 3 & 4 & -- & 120 & 480 & .07 & $<1$ & 2 & 230 \\
\hline \multirow[t]{3}{*}{1700 South Street } & -- & -- & 2 & 5 & $<5$ & 49 & 90 & -- & 1 & 1 & 130 \\
\hline & 6 & $<1$ & 1 & 5 & - & 54 & 130 & .04 & $<1$ & -- & 130 \\
\hline & 14 & $<1$ & 3 & 4 & - & 73 & 200 & .06 & $<1$ & 1 & 250 \\
\hline \multirow[t]{3}{*}{500 North Street } & -- & -- & 3 & 10 & 20 & 44 & 130 & - & 1 & 2 & 145 \\
\hline & 10 & $<1$ & 1 & 6 & -- & 47 & 200 & .04 & $<1$ & -- & 330 \\
\hline & 12 & $<1$ & 2 & 7 & -- & 39 & 110 & .06 & $<1$ & 1 & 140 \\
\hline \multicolumn{12}{|c|}{ Tributaries } \\
\hline \multirow{3}{*}{$\begin{array}{c}\text { Little Cottonwood } \\
\text { Creek }\end{array}$} & -- & -- & 2 & 7 & 10 & 67 & 250 & -- & $<1$ & 1 & 395 \\
\hline & 18 & $<1$ & $\overline{1}$ & 3 & - & 50 & 210 & .04 & $<1$ & -- & 400 \\
\hline & 15 & $<1$ & 2 & 2 & -- & 34 & 200 & .04 & $<1$ & 1 & 270 \\
\hline \multirow{3}{*}{$\begin{array}{l}\text { Big Cottonwood } \\
\text { Creek }\end{array}$} & -- & -- & -- & -- & -- & -- & -- & -- & -- & -- & -- \\
\hline & 8 & $<1$ & 1 & 6 & -- & 23 & 50 & .03 & $<1$ & -- & 75 \\
\hline & 20 & $<1$ & 1 & 3 & -- & 35 & 230 & .02 & $<1$ & 1 & 390 \\
\hline \multirow[t]{3}{*}{ Mili Creek } & -- & -- & -- & -- & -- & -- & -- & - & -- & -- & -- \\
\hline & -- & -- & 4 & 20 & 30 & 80 & 180 & -- & 3 & 3 & 240 \\
\hline & 14 & $<1$ & 3 & 10 & - & 59 & 220 & .09 & $<1$ & 1 & 210 \\
\hline
\end{tabular}


With the exception of copper and $z i n c$, concentrations of trace elements in bottom materials in Little Cottonwood, Big Cottonwood, and Mill Creeks were similar to the concentrations in the Jordan River at the three downstream sampling sites. Concentrations of zinc were generally larger in the three tributaries than in the Jordan River, whereas concentrations of copper generally were smaller in the tributaries. Copper, lead, and zinc had the largest concentrations whereas arsenic, cadmium, chromium, mercury, selenium, and silver were found in smaller concentrations at the three tributaries.

Trace elements in bottom materials are potential sources of toxicity to the aquatic environment, however, State standards for bottom materials are not available. Trace elements may be reintroduced to the aquatic environment by changes in water chemistry, dredging, or other processes. Many of the chemical mechanisms that may reintroduce trace elements to the aquatic environment are complex. A more intensive investigation would be required to determine if trace-element concentrations in bottom materials of the Jordan River or its major tributaries may be harmful.

The three major tributaries to the Jordan River were sampled near their confluence with the river. Problem concentrations of ammonia, cadmium, copper, iron, mercury, and zinc were detected in samples from Little Cottonwood Creek (table 6). Problem concentrations of ammonia, cadmium, copper, mercury, and $z$ inc were detected in samples from Big Cottonwood Creek. Problem concentrations of cadmium, copper, and mercury were detected in samples from Mill Creek.

\section{Ioxic Substances in Storm Runoff From Urban Areas}

Samples were collected during rainstorms to determine if runoff from the major urban areas caused a toxic-substance problem in the Jordan River and its three major tributaries. Major storm conduits that drain the urban areas and empty directly into the river were sampled for toxic substances during storm and nonstorm periods (table 9). Most problem concentrations were detected in samples collected during storm runoff. Cadmium, copper, lead, mercury, and zinc, which were detected in significant concentrations during storm runoff, may be washed off the impermeable parts of the urban areas and transported to the storm conduits and then rapidly to the Jordan River.

Problem concentrations of toxic substances in storm samples from the Jordan River and Little Cottonowood, Big Cottonwood, and Mill Creeks show no obvious trends when compared to nonstorm samples or when compared from site to site (table 6). Storm samples from the storm conduits however, do show increases in the number of problem concentrations of toxic substances when compared to nonstorm samples (table 9). Apparently the Jordan River and its major tributaries, which are the receiving waters for this storm water, had a sufficient volume of water to dilute the storm-water inflow, thus reducing the possibility of problem concentrations in the river due to urban-storm runoff. 
Table 9.--Toxic substances that exceeded selected concentrations in storm conduits

Number of samples: -- indicates that no sample exceeded the selected concentration.

First I ine--Number of samples that exceeded selected concentrations.

Second I ine--Number of above samples collected during storm runoff.

Third I I ne--Totai number of samples.

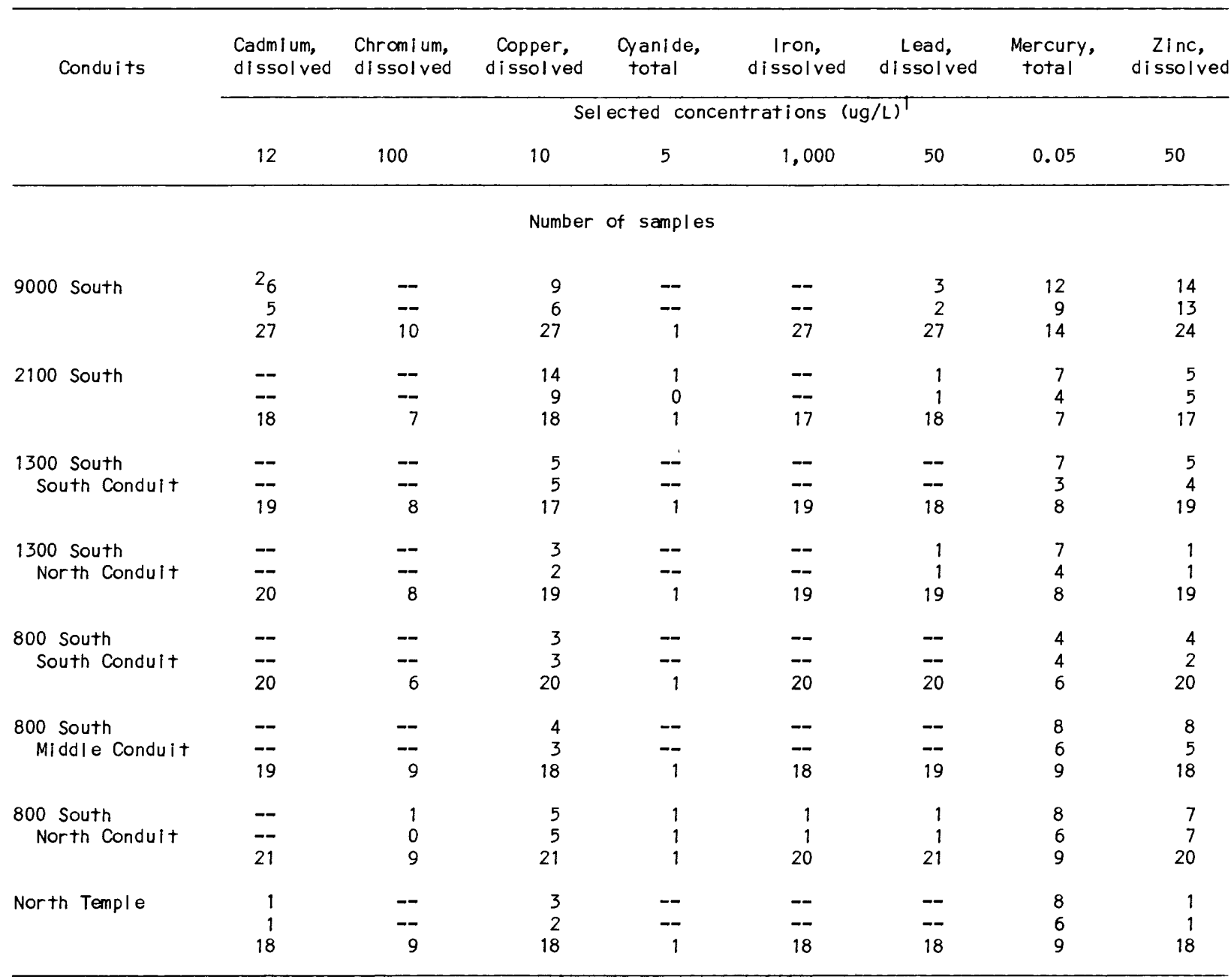

1 Selected concentrations are similar to state standards; however, State standards do not apply at these

2 A selected concentration of $1.2 \mathrm{ug} / \mathrm{L}$ of cadmium was used at 9000 South Street to agree with the State $3 \mathrm{~A}$ standard for the Jordan River in this reach. 


\author{
Priority Pollutants and Additional Trace \\ El ements in Storm Runoff from Urban Areas \\ Detected in Storm Conduits
}

The U.S. Environmental Protection Agency prepared a list of priority pollutants of environmental interest which is shown in Kelth and Telliard (1979, p. 417-419). From this list, 112 organic compounds, 13 metals, cyanide, and phenol were chosen for analysis from samples obtained at six major storm conduits that discharge into the Jordan River. These storm conduits, which drain the major urban areas of Salt Lake City, were sampled during a rainstorm on October $29,1981$.

Of the 112 organic compounds (table 10) for which analyses were made by the Utah Biomedical Test Laboratories, Salt Lake City, Utah, only one compound was detected. A concentration of 12 micrograms per liter of chloroform was detected in a water sample from the Middle Conduit of the 800 South Street Conduit.

Additional analyses made for 13 total metals, cyanide, and phenol showed large concentrations of lead and zinc in the discharge from most of the storm conduits (table 11). The maximum lead concentration was 340 micrograms per liter from the North Temple Street Conduit, and the maximum zinc concentration was 230 micrograms per liter from the 1300 South Conduit, South Conduit. The mean lead and zinc concentrations from all six storm conduits were 194 and 152 micrograms per liter.

Large concentrations of copper and phenol were found in most of the storm conduits. The maximum copper concentration was 38 micrograms per Iiter; and the maximum phenol concentration was 30 micrograms per liter.

Water samples from the October 29 storm al so were analyzed for 13 trace elements which are not included among the priority pollutants listed by the U.S. Environmental Protection Agency (table 12). Al um inum and iron had the greatest concentrations. The maximum total al uminum and iron concentrations were 11,100 and 8,920 micrograms per liter, both at the North Temple Conduit.

\title{
Iransport of Trace Elements
}

Standards for specific toxic substances may be given in the dissolved, total, or total-recoverable phase. The U.S. Environmental Protection Agency (1976) uses total or total recoverable concentrations to describe many toxic substances, whereas the State of Utah primarily uses dissolved concentrations to describe many of the same constituents (Utah Department of Soclal Services, Division of Health, 1978). It is helpful, therefore, to know how constituents are transported in a particular waterway, such as the Jordan River and its major tributaries. 
Table 10.--Organic priority pollutants sampled on October 29, 1981, at six storm conduits

VOLATILE COMPOUNDS

acrolein

acrylonitrile

benzene

bis (chloromethy I) ether

bromodichl oromethane

bromotorm

bromometh ane

carbon tetrachloride

chl orobenzene

chl orodibromomethane

chl oroeth ane

2-chloroethylvinyl ether

chl oroform

chl orometh ane

dich l orodi f l uorometh ane

1,1-dichl oroethane

1,2-dichl oroeth ane

$1,1-d i c h l$ oroethene

trans-1,2-dichl oroethene

dichl oromethane

1,2-dichl oropropane

cis-1,2-dichl oropropene

trans-1,3-dich l oropropene

ethyl benzene

$1,1,2,2$-tetrachl oroeth ane tetrachl oroethene

tol uene

$1,1,1-\operatorname{tr} i \mathrm{chl}$ oroethane

$1,1,2-t r i c h$ loroethane

trichloroethene

trichl or of I uoromethane

vinyl chloride
BASE/NEUTRAL

COMPOUNDS

acenaph thene

acenaph thy lene

anthracene

benzo(a)anthracene

benzo (b) fl uoranthene

benzo(k) fl uor anthene

benzo(a)pyrene

benzo(ghi)perylene

benzidine

benzyl buty I phthal ate

b is (2-chl oroethoxy) me thane

b is (2-chl oroethy I) ether

b is (2-chl oroi sopropy I)ether

b is (2-ethy I hexy I) ph thal ate

4-bromophenyl phenyl ether

2-chl or onaph thal ene

4-chlorophenyl phenyl ether

chrysene

dibenzo $(a, h)$ anthracene

di-n-butyl phthal ate

1,2-dichl orobenzene

1,3-dichl orobenzene

1,4-dichl orobenzene

3,3'-dichl orobenz idine

diethyl phthalate

dimethyl phthal ate

2,4-dinitrotol uene

2,6-dinitrotol uene

di-n-octyl phthalate

1,2-di pheny hydraz ine

fl uoranthene

fl uorene

hexachl orobenzene

hexach I orobutadi ene

hexachl orocyclopentadiene

hexach I oroeth ane

indeno (1,2,3-cd) pyrene

i sophorone

naphthal ene

nitrobenzene

$N$-nitrosodimethy I am i ne

N-nitrosodi phenyl ami ne

N-nitrosodi-n-propy lam ine

phenanthrene

pyrene

1,2,4-trich l orobenzene
ACID COMPOUNDS

4-chloro-3-methy I phenol

2-chl orophenol

2,4-dichl orophenol

2,4-dimethy I phenol

2,4-dinitrophenol

2-methy I-4, 6-dinitrophenol

2-nitrophenol

4-nitrophenol

pentachl orophenol

2,4,6-trichl orophenol

\section{PESTICIDE COMPQUNDS}

aldrin

al pha $\mathrm{BHC}$

beta BHC

gamma BHC

delta BHC

chlordane

$4,4^{\prime}$-DDD

4,4 '-DDE

$4,4^{\prime}$-DDT

dieldrin

endosulfan I

endosulfan II

endosul fan sulfate

endrin

heptachl or

heptachlor epoxide

PCB-1016

PCB-1221

PCB-1232

$\mathrm{PCB}-1242$

PCB-1248

PCB-1254

PCB-1260

toxaphene 
Table 11.--Selected metals, cyanide, and phenol in samples collected from six storm conduits on October 29, 1981, for analysis of priority pollutants

[Analyses by Utah Biomedical Test Laboratories, Sal + Lake City, Utah.]

Concentration: ND, not detected.

\begin{tabular}{|c|c|c|c|c|c|c|c|}
\hline \multirow{4}{*}{$\begin{array}{l}\text { Constituent } \\
\text { (total) }\end{array}$} & \multirow{4}{*}{$\begin{array}{l}\text { Limit of } \\
\text { detection } \\
(u g / L)\end{array}$} & \multicolumn{6}{|c|}{ Sampling site } \\
\hline & & \multicolumn{2}{|c|}{1300 South Street } & \multicolumn{3}{|c|}{800 South Street } & \multirow{2}{*}{$\begin{array}{l}\text { North Temple } \\
\text { Street }\end{array}$} \\
\hline & & $\begin{array}{l}\text { South } \\
\text { Conduit }\end{array}$ & $\begin{array}{l}\text { North } \\
\text { Conduit }\end{array}$ & $\begin{array}{l}\text { South } \\
\text { Conduit }\end{array}$ & $\begin{array}{l}\text { Middle } \\
\text { Conduit }\end{array}$ & $\begin{array}{c}\text { North } \\
\text { Conduit }\end{array}$ & \\
\hline & & \multicolumn{6}{|c|}{ Concentration (ug/L) } \\
\hline Antimony & 2 & ND & ND & ND & ND & ND & ND \\
\hline Arsenic & 2 & 10 & 12 & 14 & 9 & 9 & 15 \\
\hline Bery IIIum & 5 & ND & ND & ND & ND & ND & ND \\
\hline Cadmi um & 2 & 2 & ND & 2 & ND & ND & ND \\
\hline Chrom i um & 2 & 32 & 29 & 21 & 100 & 51 & 83 \\
\hline Copper & 1 & 38 & 17 & 20 & 4 & 24 & 25 \\
\hline Lead & 2 & 270 & 130 & 150 & 86 & 190 & 340 \\
\hline Mercury & .2 & ND & ND & ND & ND & ND & ND \\
\hline Nickel & 10 & ND & ND & ND & ND & ND & ND \\
\hline Seleni um & 2 & 2 & ND & ND & ND & ND & ND \\
\hline Silver & 5 & ND & ND & ND & ND & ND & ND \\
\hline Thall i um & 5 & ND & ND & ND & ND & ND & ND \\
\hline Zinc & 10 & 230 & 100 & 170 & 60 & 180 & 170 \\
\hline Cyanide & 20 & ND & ND & ND & ND & ND & ND \\
\hline Phenol & 10 & 20 & 20 & 20 & ND & 10 & 30 \\
\hline
\end{tabular}


Table 12.--Trace-element concentrations in storm runoff on October 29, 1981, at six storm conduits

Concentration:

[Analyses by Versar, Inc., Springfield, Va.]

First line--Total concentration.

Second line--Dissolved concentration.

\begin{tabular}{|c|c|c|c|c|c|c|}
\hline \multirow{4}{*}{ Constituent } & \multicolumn{6}{|c|}{ Sampling site } \\
\hline & \multicolumn{2}{|c|}{1300 South Street } & \multicolumn{3}{|c|}{800 South Street } & \multirow{2}{*}{$\begin{array}{l}\text { North Temple } \\
\text { Street }\end{array}$} \\
\hline & $\begin{array}{l}\text { South } \\
\text { Conduit }\end{array}$ & $\begin{array}{l}\text { North } \\
\text { Condult }\end{array}$ & $\begin{array}{l}\text { South } \\
\text { Conduit }\end{array}$ & $\begin{array}{l}\text { Middle } \\
\text { Conduit }\end{array}$ & $\begin{array}{c}\text { North } \\
\text { Condult }\end{array}$ & \\
\hline & \multicolumn{6}{|c|}{ Concentration (ug/L) } \\
\hline Al um i num & $\begin{array}{r}3,650 \\
50\end{array}$ & $\begin{array}{r}3,000 \\
50\end{array}$ & $\begin{array}{r}4,600 \\
<50\end{array}$ & $\begin{array}{r}1,600 \\
50\end{array}$ & $\begin{array}{r}3,850 \\
150\end{array}$ & $\begin{array}{r}11,100 \\
150\end{array}$ \\
\hline Barium & $\begin{array}{r}120 \\
40\end{array}$ & $\begin{array}{l}70 \\
40\end{array}$ & $\begin{array}{r}130 \\
40\end{array}$ & $\begin{array}{l}50 \\
30\end{array}$ & $\begin{array}{r}130 \\
20\end{array}$ & $\begin{array}{r}150 \\
40\end{array}$ \\
\hline Boron & $\begin{array}{l}100 \\
110\end{array}$ & $\begin{array}{l}60 \\
80\end{array}$ & $\begin{array}{l}140 \\
110\end{array}$ & $\begin{array}{r}80 \\
100\end{array}$ & $\begin{array}{r}100 \\
50\end{array}$ & $\begin{array}{l}70 \\
50\end{array}$ \\
\hline Cobalt & $\begin{array}{l}<10 \\
<10\end{array}$ & $\begin{array}{l}<10 \\
<10\end{array}$ & $\begin{array}{l}<10 \\
<10\end{array}$ & $\begin{array}{l}<10 \\
<10\end{array}$ & $\begin{array}{l}<10 \\
<10\end{array}$ & $\begin{array}{l}<10 \\
<10\end{array}$ \\
\hline Iron & $\begin{array}{r}3,720 \\
80\end{array}$ & $\begin{array}{r}2,740 \\
60\end{array}$ & $\begin{array}{r}4,480 \\
60\end{array}$ & $\begin{array}{r}1,760 \\
80\end{array}$ & $\begin{array}{r}4,900 \\
140\end{array}$ & $\begin{array}{r}8,920 \\
140\end{array}$ \\
\hline Lith i um & $\begin{array}{l}30 \\
30\end{array}$ & $\begin{array}{l}10 \\
10\end{array}$ & $\begin{array}{l}20 \\
20\end{array}$ & $\begin{array}{l}20 \\
20\end{array}$ & $\begin{array}{l}<10 \\
<10\end{array}$ & $\begin{array}{r}20 \\
<10\end{array}$ \\
\hline Manganese & $\begin{array}{r}110 \\
40\end{array}$ & $\begin{array}{l}80 \\
40\end{array}$ & $\begin{array}{r}120 \\
40\end{array}$ & $\begin{array}{l}60 \\
30\end{array}$ & $\begin{array}{r}110 \\
20\end{array}$ & $\begin{array}{r}220 \\
50\end{array}$ \\
\hline Molybdenum & $\begin{array}{l}<10 \\
<10\end{array}$ & $\begin{array}{l}<10 \\
<10\end{array}$ & $\begin{array}{l}<10 \\
<10\end{array}$ & $\begin{array}{l}<10 \\
<10\end{array}$ & $\begin{array}{l}<10 \\
<10\end{array}$ & $\begin{array}{l}<10 \\
<10\end{array}$ \\
\hline Strontium & $\begin{array}{l}390 \\
370\end{array}$ & $\begin{array}{l}290 \\
330\end{array}$ & $\begin{array}{l}390 \\
350\end{array}$ & $\begin{array}{l}240 \\
240\end{array}$ & $\begin{array}{r}100 \\
70\end{array}$ & $\begin{array}{r}130 \\
90\end{array}$ \\
\hline Tin & $\begin{array}{l}<50 \\
<50\end{array}$ & $\begin{array}{l}<50 \\
<50\end{array}$ & $\begin{array}{l}<50 \\
<50\end{array}$ & $\begin{array}{l}<50 \\
<50\end{array}$ & $\begin{array}{l}<50 \\
<50\end{array}$ & $\begin{array}{l}<50 \\
<50\end{array}$ \\
\hline Titanium & $\begin{array}{l}130 \\
<10\end{array}$ & $\begin{array}{l}100 \\
<10\end{array}$ & $\begin{array}{l}180 \\
<10\end{array}$ & $\begin{array}{r}60 \\
<10\end{array}$ & $\begin{array}{l}170 \\
<10\end{array}$ & $\begin{array}{l}350 \\
<10\end{array}$ \\
\hline Vanadi um & $\begin{array}{l}<10 \\
<10\end{array}$ & $\begin{array}{l}<10 \\
<10\end{array}$ & $\begin{array}{r}10 \\
<10\end{array}$ & $\begin{array}{l}<10 \\
<10\end{array}$ & $\begin{array}{l}<10 \\
<10\end{array}$ & $\begin{array}{r}20 \\
<10\end{array}$ \\
\hline Yttrium & $\begin{array}{l}<10 \\
<10\end{array}$ & $\begin{array}{l}<10 \\
<10\end{array}$ & $\begin{array}{l}<10 \\
<10\end{array}$ & $\begin{array}{l}<10 \\
<10\end{array}$ & $\begin{array}{l}<10 \\
<10\end{array}$ & $\begin{array}{l}<10 \\
<10\end{array}$ \\
\hline
\end{tabular}




\section{Transportation as a Dissolved or Suspended Constituent}

Ten trace el ements for which there are Utah water-quality standards and that part of each which is transported in the dissol ved phase in the Jordan River, Big Cottonwood, Little Cottonwood, and Mill Creeks are listed in table 13. Chromium, copper, iron, lead, and zinc show the most variation Most of the arsenic, barium, mercury, selenium, and silver in the Jordan River is transported in the dissolved phase, as is approximately one-third of the chromium, copper, lead, and zinc. By contrast, about 98 percent of the iron in the river is transported in the suspended phase.

\section{Trace-El ement Loads in the Jordan River}

Instantaneous loads of 13 trace elements were determined for the five sampling sites on the Jordan River, and a mean load was calculated using a mean discharge for 24 hours. The mean loads shown in table 14 reflect a wide range of discharges, which is desirable to produce a more representative mean load for a specific sampling site. The variability of individual constituents al so may affect the accuracy of the mean load calculated for these constituents if only a small number of samples are used in the calculation. Thus, the number of samples used in the load calculations also is included in table 14.

The loads shown in table 14 should be considered as estimated loads that were calculated for nonstorm periods. Several of the loads for individual constituents show considerable variation from site to site. This is due principally to the various inflows and diversions that occur between sampling sites. For example, 72.4 percent of the annual flow in the Jordan River above 1700 South Street was diverted into the Surplus Canal during the 1981 water year.

Iron is transported in the greatest quantity in the Jordan River, with a mean load of 110 pounds per day. Notable loads of barium, boron, lead, and zinc also are transported by the river. A mean of 11.4 pounds per day of barium, 30.9 pounds per day of boron, 4.5 pounds per day of lead and 7.9 pounds per day of $z$ inc are transported by the river. In general about 1 to 3 pounds per day of arsenic, chromium, copper, and less than 1 pound per day of cadmium, cyanide, mercury, selenium, and silver are transported by the river. 
Table 13.--Part of selected trace elements transported in the dissolved phase in the Jordan River, Big Cottonwood, Little Cottonwood, and Mill Creeks

Standard deviation: A relative measure of variabllity.

Coefficient of variation: A dimensionless measure of variability calculated as the standard deviation expressed as a percentage of the mean.

\begin{tabular}{lcccc}
\hline $\begin{array}{c}\text { Trace } \\
\text { element }\end{array}$ & $\begin{array}{c}\text { Part of element in } \\
\text { dissolved phase } \\
\text { (mean percent) }\end{array}$ & $\begin{array}{c}\text { Number of } \\
\text { samples }\end{array}$ & $\begin{array}{c}\text { Standard } \\
\text { deviation }\end{array}$ & $\begin{array}{c}\text { Coefficient } \\
\text { of variation }\end{array}$ \\
\hline Arsenic & 90 & 13 & 8 & 8 \\
Barium & 72 & 29 & 20 & 27 \\
Chromium & 32 & 50 & 29 & 89 \\
Copper & 36 & 165 & 22 & 62 \\
Iron & 2 & 112 & 3 & 145 \\
Lead & 27 & 143 & 26 & 95 \\
Mercury & 77 & 32 & 29 & 38 \\
Selenium & 96 & 30 & 12 & 13 \\
Silver & 96 & 18 & 23 & 20 \\
Zinc & 34 & 167 & 19 & 67 \\
\hline
\end{tabular}


Table 14.--Mean loads of selected trace el ements in the Jordan River for nonstorm perlods

Load: Total load. unless noted otherwise.

First line--Mean load.

Second I Ine--Number of samples used to calculate mean load.

\begin{tabular}{|c|c|c|c|c|c|}
\hline \multirow{3}{*}{ Constituent } & \multicolumn{5}{|c|}{ site } \\
\hline & $\begin{array}{l}\text { Jordan } \\
\text { Narrows }\end{array}$ & $\begin{array}{l}9000 \\
\text { South } \\
\text { Street }\end{array}$ & $\begin{array}{l}5800 \\
\text { South } \\
\text { Street }\end{array}$ & $\begin{array}{l}1700 \\
\text { South } \\
\text { Street }\end{array}$ & $\begin{array}{c}500 \\
\text { North } \\
\text { Street }\end{array}$ \\
\hline & \multicolumn{5}{|c|}{ Load, In pounds per day } \\
\hline Arsenic & $\begin{array}{l}1.14 \\
5\end{array}$ & $\begin{array}{l}1.27 \\
4\end{array}$ & $\begin{array}{l}1.97 \\
5\end{array}$ & $16^{1.24}$ & $\begin{array}{l}1.48 \\
5\end{array}$ \\
\hline Bar i um & $\begin{array}{c}10.8 \\
5\end{array}$ & $\begin{array}{l}9.26 \\
4\end{array}$ & $\begin{array}{c}13.7 \\
5\end{array}$ & $\begin{array}{l}11.5 \\
16\end{array}$ & $\begin{array}{l}11.2 \\
5\end{array}$ \\
\hline $\begin{array}{l}\text { Boron } \\
\text { (dissolved) }\end{array}$ & $\begin{array}{c}25.8 \\
5\end{array}$ & $\begin{array}{c}29.6 \\
4\end{array}$ & $\begin{array}{c}45.4 \\
5\end{array}$ & $\begin{array}{l}24.6 \\
5\end{array}$ & $\begin{array}{l}29.0 \\
5\end{array}$ \\
\hline Cadmi um & $8^{.05}$ & $14^{.06}$ & $12^{.10}$ & $26^{.10}$ & $19^{.13}$ \\
\hline Chromium & 19.18 & $24^{1.04}$ & $23^{1.45}$ & $36^{1.04}$ & $29^{1.77}$ \\
\hline Copper & 1.03 & 24.65 & 23.34 & $\begin{array}{l}2.38 \\
36\end{array}$ & $2^{49.16}$ \\
\hline Cyanide & $\begin{array}{l}<.01 \\
5\end{array}$ & $\begin{array}{l}<.01 \\
4\end{array}$ & 24 & $\begin{array}{l}<.01 \\
5\end{array}$ & $\begin{array}{l}<.01 \\
5\end{array}$ \\
\hline Iron & $\begin{array}{r}111 \\
16\end{array}$ & $\begin{array}{l}88.1 \\
14\end{array}$ & $\begin{array}{r}110 \\
16\end{array}$ & $\begin{array}{r}109 \\
26\end{array}$ & $\begin{array}{r}129 \\
15\end{array}$ \\
\hline Lead & $19^{.72}$ & $24^{1.20}$ & $23^{6.58}$ & $36^{3.56}$ & $29^{9.35}$ \\
\hline Mercury & $18^{.02}$ & $16^{.02}$ & $18^{.02}$ & $28^{.01}$ & $17^{.01}$ \\
\hline Seleni um & $5^{.10}$ & $4^{.22}$ & $5^{.33}$ & $16^{.14}$ & $5^{.17}$ \\
\hline Sllver & $8^{.06}$ & $14^{.04}$ & $32^{.05}$ & $29^{.07}$ & $19^{.11}$ \\
\hline Zinc & ${ }_{19}^{5.10}$ & $2^{4.41}$ & $4^{8.91}$ & 36.64 & $\begin{array}{l}12.7 \\
29\end{array}$ \\
\hline
\end{tabular}




\section{SUMMARY}

A reconnalssance of toxic substances in the Jordan River was made during July 1980 to October 1982 as part of a larger study of the river that included studies of sanitary quality, dissolved oxygen, and turbidity. Separate reports were prepared for each subject and are summarized in a final report. Samples for toxic substances were collected at five sites on the Jordan River, at the mouths of three major tributaries, and at six storm conduits.

Of the toxic substances studied, concentrations of total mercury exceeded State standards most frequently. About 78 percent of the 138 samples for total mercury exceeded the State use standard of $0.05 \mathrm{microgram}$ per 1 iter. 0 ther toxic substances that exceeded State standards were: ammonla--18 percent of the samples, cadmium--9 percent, copper--9 percent, zinc--6 percent, lead--2 percent, cyanide and iron-one sample each. Arsenic, chromium, phenol, selenium, sllver, boron, endrin, lindane, and toxaphene did not exceed state standards in samples collected from the Jordan River and its three major tributaries.

The diversity of toxic substances with concentrations I arge enough to cause them to be problems increased from the most upstream sampling site at the Jordan Narrows to the next two downstream sites at 9000 South and 5800 South Streets. Concentrations of trace elements in stream-bottom materials also increased in a downstream direction Large increases first were observed at 5800 South Street, and they were sustained throughout the downstream study area. Concentrations of most trace elements in bottom materials at the mouths of the three major tributaries were similar to the concentrations in the Jordan River at the three downstream-sampling sites. Copper and $z$ inc were exceptions. The mean zinc concentration in the three major tributaries was 282.9 micrograms per gram, exceeding the mean concentration of 186.9 micrograms per gram in the three downstream Jordan River sites. The mean copper concentration in the three major tributarles was 49.7 micrograms per gram compared to the mean concentration of $64.5 \mathrm{mlcrograms}$ per gram in the three downstream Jordan River sites.

Iron is transported in the greatest quantity of all the trace el ements studied, with a mean load of 110 pounds per day. Notable loads of barium, boron, lead, and zinc al so are transported by the river. Most of the arsenic, barium, mercury, selenium, and sllver is transported in the dissolved phase, as is about one-third of the chromium, copper, lead, and zinc. Iron is transported almost totally in the suspended phase.

DDD, DDE, DDT, dieldrin, heptachlor, methoxychlor, PCB, and 2,4-D were detected in bottom-materlal samples from the Jordan River or tributaries. DDE, Silvex, and 2,4-D were detected in water samples. Most of the U.S. Environmental Protection Agency's list of priority pollutants were sampled at six storm conduits during a rainstorm on October 29, 1981. Only one of 112 organic compounds, chloroform, was detected. Several metals and phenol also were detected. 


\section{REFERENCES CITED}

Coburn, A., 1972, Pollution input from the lower Jordan River basin to Antelope |s| and estuary: Masters thesis, Department of Civil Engineering, Division of Environmental Engineering, University of Utah, $122 \mathrm{p}$.

Hydroscience, Inc., 1976, The water qual ity impact of point and nonpoint loads to the Jordan River: Salt Lake City, Salt Lake County Council of Governments, (208 study) 68 p.

Keith, L. H., and Telliard, W. A., 1979, Priority pollutants, a perspective view: Environmental Science and Technology, v. 13, no. 4, p. 416-423.

National Oceanic and Atmospheric Administration, 1981, Cl imatological data annual summary, Utah: Asheville, N. C., Environmental Data and Information Service, vol. 83, no. 13,15 p.

Salt Lake County Soil Conservation District, 1981, Jordan River agricultural nonpoint water qual ity assessment for 1979-80: Sal + Lake County Division of Water Qual ity and Water: Pollution Control, 71 p.

Skougstad, M. W., Fishman, M. J., Friedman, L. C., Erdmann, D. E., and Duncan, S. S., 1979. Methods for determination of inorganic substances in water and fluvial sediments: U.S. Geological Survey Techniques of WaterResources Investigations, Book 5, Chapter Al, 626 p.

Stephens, D. W., 1984, Characterization of the dissolved oxygen regime of the Jordan River Salt Lake County, Utah: U.S. Geological Survey WaterResources Investigations Report 84-4056, 56 p.

Templeton, Link, and Alsup, and Engineering-Science Inc., 1974, Utah LakeJordan River hydrologic basins water-qual ity management planning study: Utah State Division of Health, Bureau of Environmental Health, p. 14-32.

Thompson, K. Ro, 1984, Sanitary quality of the Jordan River in Salt Lake County, Utah: U.S. Geological Survey Water-Resources Investigations Report 83-4252, 36 p.

U.S. Environmental Protection Agency, 1976, Qual ity criteria for water: United States Government Printing Office: 1978 258-389/6057, 256 p.

U.S. Geol ogical Survey, 1977, National handbook of recommended methods for water-data acquisition: Reston, Virginia, p. 10-72.

Utah Department of Social Services, Division of Health, 1978, Wastewater disposal regulations-Part II, standards of quality for waters of the State: State of Utah, Department of Social Services, Division of Heal th, $30 \mathrm{p}$. 
Way, T., 1977, Fishery potential of the Jordan River as affected by wastewater treatment alternatives: Sal t Lake City, Salt Lake County Council of Governments (208 study), 121 p.

Weigel, J. F., 1984, Turbidity and suspended sediment in the Jordan River, Salt Lake County, Utah: U.S. Geological Survey Water-Resources Investigations Report 84-4019, 17 p.

Willingham, W. J., 1976, Ammonia toxicity: U.S. Environmental Protection Agency Region VIII, Control Technology Branch Water Division, EPA-908/376-001, $73 \mathrm{p}$. 